\title{
Ramped thermal analysis for isolating biologically meaningful soil organic matter fractions with distinct residence times
}

\author{
Jonathan Sanderman ${ }^{1}$ and A. Stuart Grandy ${ }^{2}$ \\ ${ }^{1}$ Woods Hole Research Center, Falmouth, MA 02540, USA \\ ${ }^{2}$ Department of Natural Resources and the Environment, University of New Hampshire, \\ Durham, NH 03824, USA
}

Correspondence: Jonathan Sanderman (jsanderman@whrc.org)

Received: 8 July 2019 - Discussion started: 21 August 2019

Revised: 17 February 2020 - Accepted: 19 February 2020 - Published: 6 April 2020

\begin{abstract}
In this work, we assess whether or not ramped thermal oxidation coupled with determination of the radiocarbon content of the evolved $\mathrm{CO}_{2}$ can be used to isolate distinct thermal fractions of soil organic matter (SOM) along with direct information on the turnover rate of each thermal fraction. Using a 30-year time series of soil samples from a well-characterized agronomic trial, we found that the incorporation of the bomb spike in atmospheric ${ }^{14} \mathrm{CO}_{2}$ into thermal fractions of increasing resistance to thermal decomposition could be successfully modeled. With increasing temperature, which is proportional to activation energy, the mean residence time of the thermal fractions increased from 10 to 400 years. Importantly, the first four of five thermal fractions appeared to be a mixture of fast- and increasingly slower-cycling SOM. To further understand the composition of different thermal fractions, stepped pyrolysis-gas chromatography-mass spectrometry (Py-GC/MS) experiments were performed at five temperatures ranging from 330 to $735^{\circ} \mathrm{C}$. The Py-GC/MS data showed a reproducible shift in the chemistry of pyrolysis products across the temperature gradient trending from polysaccharides and lipids at low temperature to lignin- and microbe-derived compounds at middle temperatures to aromatic and unknown compounds at the highest temperatures. Integrating the ${ }^{14} \mathrm{C}$ and $\mathrm{Py}-\mathrm{GC} / \mathrm{MS}$ data suggests the organic compounds, with the exception of aromatic moieties likely derived from wildfire, with centennial residence times are not more complex but may be protected from pyrolysis, and likely also from biological mineralization, by interactions with mineral surfaces.
\end{abstract}

\section{Introduction}

Soil organic matter (SOM) consists of a spectrum of material from labile, rapidly cycling compounds to mineral-stabilized molecules that resist degradation for centuries. This spectrum of turnover rates is due to a combination of organic matter composition with varying reactivity, various degrees of interaction between organic and mineral phases and greatly varying microclimates more or less suited to microbial activity (Lehmann and Kleber, 2015; Ruamps et al., 2013; Schmidt et al., 2011). Soil scientists often deal with this complexity by fractionating SOM into what are thought to be more homogenous pools in terms of reactivity, composition or microbial accessibility depending on the particulars of the study (Christensen, 2001; von Lützow et al., 2007). Similarly, soil carbon cycle models typically divide SOM into conceptual pools with distinct mean turnover rates (Manzoni and Porporato, 2009). However, empiricists have been trying for decades with varying degrees of success to link physically and chemically isolated fractions of SOM to the conceptual SOM pools in carbon cycle models (Skjemstad et al., 2004; Zimmermann et al., 2007).

Fractionation schemes - employing various physical, chemical, biological or thermal methods - are generally used to reduce the inherent complexity found in SOM. Both size fractionation and density separation are commonly used to 
separate particulate from mineral-associated SOM (Elliott and Cambardella, 1991; Golchin et al., 1994; Sollins et al., 2009). Hydrolysis with strong acid has been shown to isolate SOM that is consistently hundreds to thousands of years older than the bulk SOM (Paul et al., 2001). Biological fractionation involves the modeling of mass loss or $\mathrm{CO}_{2}$ evolution during a laboratory incubation experiment (Grandy and Robertson, 2007; Schädel et al., 2013). Baldock et al. (2013), recognizing that fire-derived pryogenic carbon $(\mathrm{PyC})$ has distinct properties from plant or microbial products, combined physical size fractionation with the use of solid-state ${ }^{13} \mathrm{C}$ nuclear magnetic resonance spectroscopy to mathematically isolate the $\mathrm{PyC}$ fraction from each size fraction. There are advantages and disadvantages to each of these techniques (Poeplau et al., 2018), but even the most detailed fractionation schemes are unable to isolate homogenous SOM pools (Jastrow et al., 1996; Sanderman et al., 2013; Torn et al., 2013), which may be as much a result of methodological issues as the fact that there are multiple pathways for SOM formation (Cotrufo et al., 2013; Sokol et al., 2019).

Thermal analysis techniques, long used in petrochemical exploration and clay mineralogy, offer a promising alternative or complement to physically and chemically based fractionation methods and are increasingly being applied to studies of SOM stability and loss (Peltre et al., 2013; Plante et al., 2009; Williams et al., 2018). The basic premise of this suite of tools is that by slowly heating a sample the energy needed to evolve the carbon at different temperatures, whether that comes from breaking an organic-organic bond or disrupting an organic-mineral bond or other association, can be quantified and that this energy yield is somewhat related to the energy requirements for enzymatic degradation of SOM (Williams and Plante, 2018). While research suggests that more complex organic molecules have higher thermal stability (Lopez-Capel et al., 2005; Yang et al., 2006), contradictory results have also been reported (Rovira et al., 2008). Several studies have also found good correlations between thermal stability indices and biological stability (Peltre et al., 2013; Soucémarianadin et al., 2018) and model-derived stable C pools (Cécillon et al., 2018). However, other studies have found that new carbon preferentially flowed into more thermally stable fractions (Helfrich et al., 2010; Schiedung et al., 2017), suggesting that the relationship between thermal stability and SOM cycling concepts may not be straightforward.

A recent advance in thermal analysis is the coupling of a temperature-controlled oven to a vacuum line, termed ramped pyrolysis-oxidation (RPO), enabling collection of evolved gas at distinct temperature regions for subsequent ${ }^{13} \mathrm{C}$ and ${ }^{14} \mathrm{C}$ analysis (Rosenheim et al., 2008). Unlike interpretation of other thermal indices, ${ }^{14} \mathrm{C}$ is a direct and powerful tracer of soil carbon cycling by providing information on the age and turnover rate of an isolated fraction of SOM (Trumbore, 2009; Trumbore et al., 1996). In the first application of the RPO system to SOM, Plante et al. (2013) found that more thermally stable fractions also contained the oldest, most ${ }^{14} \mathrm{C}$-depleted carbon.

In this study, we present the first use of ramped thermal analysis with a time series of soil samples to investigate the carbon cycling rate of SOM with increasing thermal stability. The use of a multidecadal time series of soil samples allows for modeling the uptake of the bomb spike in atmospheric ${ }^{14} \mathrm{CO}_{2}$ due to nuclear weapons testing into SOM fractions in order to determine the turnover rate of those fractions (Baisden et al., 2013). We further couple the ${ }^{14} \mathrm{C}$-based turnover time estimates with parallel chemical characterization of similar thermal fractions using a stepped pyrolysisgas chromatography-mass spectrometry (Py-GC/MS) approach. With the compound-specific chemistry data we are aiming to be able to start to explain possible mechanisms controlling the turnover of the thermal fractions and thereby provide new insights into the linkages between thermal stability, SOM composition and microbial cycling of SOM.

\section{Materials and methods}

\subsection{Trial and soil description}

The soil used in this study comes from a long-term agricultural research trial evaluating alternative crop rotations located at the Waite Research Institute in South Australia $\left(34.967^{\circ} \mathrm{S}, 138.634^{\circ} \mathrm{E}\right)$, with a Mediterranean climate, where $80 \%$ of the $626 \mathrm{~mm}$ of average rainfall occurs during the April-October growing season. The soil is classified as a Rhodoxeralf in the USDA taxonomy (Soil Survey Staff, 1999) or a Chromic Luvisol in the World Reference Base taxonomy (IUSS Working Group WRB, 2015) with a fine sandy loam texture in the upper horizons, and a mean $\mathrm{pH}\left(\mathrm{H}_{2} \mathrm{O}\right)$ of 5.9 and clay content of $18 \%$ for the 0 $10 \mathrm{~cm}$ layer (Grace et al., 1995). Full trial history including management records, agronomic performance and soil data have been reported elsewhere (Grace et al., 1995; Sanderman et al., 2017). These data, including monthly climate records, can be accessed from the Commonwealth Scientific and Industrial Research Organisation (CSIRO) Data Access Portal (https://doi.org/10.4225/08/55E5165EC0D29).

For this study, we have chosen to focus on the permanent pasture treatment because previous work (Sanderman et al., 2017) found the greatest uptake of the bomb spike in atmospheric ${ }^{14} \mathrm{CO}_{2}$ in this treatment. This particular trial strip (\#29) was under a wheat-pea rotation from 1925 until 1950 but then converted to an improved pasture by sowing a mix of annual rye grass, subterranean clover and Phalaris in 1950 and was then managed consistently with simulated grazing (i.e., hand mowing) and periodic re-sowing until the end of the trial in 1996. In April of 1963, 1973, 1983 and 1993 soil samples from the top $10 \mathrm{~cm}$ were collected as a composite of 20 cores taken along the center line of this $90 \mathrm{~m}$ long strip trial. Soils were dried at $40^{\circ} \mathrm{C}$ for $>48 \mathrm{~h}$ before being stored in glass jars prior to subsampling in 2015. Previous analy- 
ses (Sanderman et al., 2016, 2017) suggest that SOM and the proportion in a particulate fraction only varied slightly throughout the 1963-1993 period (Table 1). The large change in $\triangle^{14} \mathrm{C}$ was due to uptake and loss of the bomb spike in atmospheric ${ }^{14} \mathrm{CO}_{2}$.

\subsection{Ramped pyrolysis-oxidation}

Ramped pyrolysis-oxidation (RPO) was performed using the Dirt Burner, a custom-built evolved gas system at the National Ocean Sciences Accelerator Mass Spectrometry (NOSAMS) facility, where a sample can be linearly heated under either pyrolyzing or oxidizing conditions. The evolved gases are then oxidized to $\mathrm{CO}_{2}$, measured on an in-line infrared gas analyzer and trapped for subsequent analysis of ${ }^{13} \mathrm{C}$ and ${ }^{14} \mathrm{C}$ composition. Initial instrument development is described by Rosenheim et al. (2008) with upgrades described by Plante et al. (2013). See Hemingway et al. (2017b) for a complete description of current instrument configuration and operating conditions. In this investigation we operated the Dirt Burner only in oxidizing mode. It has been demonstrated that the distribution of activation energies and ${ }^{14} \mathrm{C}$ age of thermal fractions for soil are similar under oxidizing and pyrolysis modes (Grant et al., 2019). The 1973 soil sample was initially run using a fast ramp $\left(20^{\circ} \mathrm{C} \mathrm{min}^{-1}\right)$ where only $\mathrm{CO}_{2}$ concentration was recorded. Using an inversion method (Hemingway et al., 2017a), five distinct thermal fractions were identified from this thermogram with temperature ranges of 100-325, 325-400, 400-445, 445-515 and $>515^{\circ} \mathrm{C}$ (Fig. A1). Subsequently, $45 \mathrm{mg}$ of each soil sample were combusted on the Dirt Burner using a slow temperature ramp $\left(5^{\circ} \mathrm{Cmin}^{-1}\right)$, and the evolved $\mathrm{CO}_{2}$ in each of these five fractions was cryogenically collected and purified for subsequent analyses. The RPO fractions were then split for ${ }^{13} \mathrm{C}$ analysis on a dual-inlet isotope ratio mass spectrometer (McNichol et al., 1994b) and ${ }^{14} \mathrm{C}$ composition via accelerator mass spectrometry after graphitization (McNichol et al., 1994a). Stable isotope data are expressed in $\delta^{13} \mathrm{C}$ notation (\%o) relative to the Vienna Pee Dee Belemnite (VPDB) standard. Radiocarbon data, after using ${ }^{13} \mathrm{C}$ data to correct for mass-dependent fractionation, are reported from NOSAMS as fraction modern (Fm, where the 1950 atmosphere is assigned a value of 1.0) and subsequently converted to the geochemical $\Delta^{14} \mathrm{C}$ notation (Stuiver and Polach, 1977) for bomb-spike modeling.

\subsection{Pyrolysis-gas chromatography-mass spectrometry}

We determined the relative percentages and ratios of chemical classes using pyrolysis-mass spectrometry-gas chromatography (Py-GC/MS) using methods described previously (Grandy et al., 2009; Kallenbach et al., 2015; Wickings et al., 2011). However, in contrast to our previous studies in which we used a single pyrolysis temperature, here we used a "ramp" or stepped approach by pyrolyzing the same sam- ple at five distinct, sequentially increasing temperatures: 330 , 396, 444, 503 and $735^{\circ} \mathrm{C}$ (Buurman et al., 2007; Hempfling and Schulten, 1990; Williams et al., 2014). Thus, the same sample was pyrolyzed five times, corresponding with each of these temperatures. Temperatures were chosen to correspond with the temperature ranges from the RPO analysis. Samples were pyrolyzed at each temperature and pyrolysis products transferred to a GC, where compounds were separated on a $60 \mathrm{~m}$ capillary column with a starting temperature of $40^{\circ} \mathrm{C}$ followed by a temperature ramp of $5^{\circ} \mathrm{C} \mathrm{min}^{-1}$ to $270^{\circ} \mathrm{C}$ followed by a final ramp $\left(30^{\circ} \mathrm{Cmin}^{-1}\right)$ to $300^{\circ} \mathrm{C}$. Compounds were immediately transferred from the GC to an ion trap MS, where they were ionized at $70 \mathrm{eV}$ in the electronicionization mode with the source temperature held at $200^{\circ} \mathrm{C}$, detected via electron multiplier, and identified using a compound library built using the National Institute of Standards and Technology (NIST) database and published literature as reported previously (Grandy et al., 2007, 2009). Individual compounds were classified by their source as polysaccharide, aromatic, phenolic, protein, $\mathrm{N}$-bearing (non-proteins) or unknown. Proteins include pyridines, pyrroles and indoles, which have been previously identified as pyrolysis products of proteins (Schulten and Schnitzer, 1997). The compounds that are in the unknown category are identified but can be derived in nature or due to pyrolysis from different sources (e.g., both protein and aromatic).

\subsection{Data analysis}

The turnover time of each thermal fraction was determined by modeling the incorporation of the bomb spike in atmospheric ${ }^{14} \mathrm{CO}_{2}$ into each fraction (Baisden et al., 2013). We have applied a steady-state soil carbon turnover model to each thermal fraction where carbon inputs $\left(\mathrm{C}_{\mathrm{in}}\right)$ are portioned into each model pool proportional to the fractional distribution of carbon in each pool $\left(f_{\text {pool }}\right)$ with the ${ }^{14} \mathrm{C} /{ }^{12} \mathrm{C}$ ratio of the previous year's atmospheric $\mathrm{CO}_{2}$ (data from Currie et al., 2011). Carbon losses follow first-order kinetics with a characteristic decay rate for each pool $\left(k_{\text {pool }}\right)$, and shifts in ${ }^{14} \mathrm{C} /{ }^{12} \mathrm{C}$ ratio are also affected by radioactive decay $\left(\lambda=1.21 \times 10^{-4} \mathrm{yr}^{-1}\right)$. Turnover time $\left(\tau_{\text {pool }}\right)$ is simply the inverse of the decay rate for each pool. First, we assumed that each thermal fraction is a single homogenous pool and solve the turnover model to find a single $k$ value by minimizing the sum of square errors (SSE) between observed and predicted $\Delta^{14} \mathrm{C}$ data for the four years of data $(1963,1973$, 1983 and 1993) for that particular thermal fraction. Initial results suggested that most of the thermal fractions could not be represented as a single homogenous pool, so we then applied a two-pool model by assuming a fixed $k$ for the fastcycling pool $\left(k_{\text {fast }}=0.25 \mathrm{yr}^{-1}\right)$ and allowed the size $\left(f_{\text {slow }}\right)$ and decay rate $\left(k_{\text {slow }}\right)$ of the slow-cycling pool to vary while minimizing the SSE between observed and predicted $\Delta^{14} \mathrm{C}$ data for each thermal fraction. Given the limited number of degrees of freedom, we decided not to allow for the simul- 
Table 1. Previously reported organic matter properties measured on the soils used in this study.

\begin{tabular}{|c|c|c|c|c|c|c|c|c|c|c|}
\hline \multirow[b]{2}{*}{ Year } & \multirow[b]{2}{*}{ SOC (\%) } & \multirow[b]{2}{*}{$\mathrm{TN}(\%)$} & \multirow[b]{2}{*}{$\mathrm{C} / \mathrm{N}$} & \multirow[b]{2}{*}{$\Delta^{14} \mathrm{C}(\% \circ)$} & \multirow[b]{2}{*}{$\delta^{13} \mathrm{C}(\% o)$} & \multicolumn{2}{|c|}{ Size fractions ${ }^{1}$} & \multicolumn{3}{|c|}{ Adelaide fractions $^{2}$} \\
\hline & & & & & & $f_{>} 50 \mu \mathrm{m}$ & $f_{<50 \mu \mathrm{m}}$ & $f_{\mathrm{POC}}$ & $f_{\mathrm{HOC}}$ & $f_{\mathrm{ROC}}$ \\
\hline 1963 & 2.80 & 0.25 & 11.3 & 16.7 & -26.5 & 0.27 & 0.73 & 0.17 & 0.54 & 0.29 \\
\hline 1973 & 2.49 & 0.22 & 11.2 & 132.4 & -26.0 & 0.24 & 0.76 & 0.16 & 0.55 & 0.29 \\
\hline 1983 & 2.48 & 0.23 & 10.8 & 118.4 & -26.4 & 0.23 & 0.77 & 0.15 & 0.55 & 0.30 \\
\hline 1993 & 2.46 & 0.24 & 10.4 & 95.6 & -26.6 & 0.23 & 0.77 & 0.16 & 0.55 & 0.28 \\
\hline
\end{tabular}

\footnotetext{
${ }^{1}$ Measured distribution of SOC into $>$ and $<50 \mu \mathrm{m}$ size fractions following dispersion and wet sieving.

2 Predicted distribution into particulate, humus and resistant organic carbon (POC, HOC and ROC, respectively) fractions (Baldock et al. 2013a) using a mid-infrared-spectroscopy-based predictive model (Baldock et al. 2013b)
}

taneous optimization of all three parameters. The value for $k_{\text {fast }}$ was set at $0.25 \mathrm{yr}^{-1}$ after performing a simple sensitivity analysis where $k_{\text {fast }}$ was varied from 0.1 to $1.0 \mathrm{yr}^{-1}$ and $f_{\text {slow }}$ and $k_{\text {slow }}$ were optimized. This exercise suggested that the overall lowest mean root mean square error (RMSE) across thermal fractions was achieved with $k_{\text {fast }}=0.25 \mathrm{yr}^{-1}$. Model performance was assessed by calculating the RMSE between observed and predicted $\Delta^{14} \mathrm{C}$ values.

The stepped Py-GC/MS data are reported as percent relative abundance for each identified compound. We present these data qualitatively in two ways. First, data from each thermal interval were averaged across years, and shifts in the eight major compound classes are shown. Second, all compounds that averaged $>1 \%$ abundance across all 20 samples (4 years $\times 5$ thermal intervals) were included in a non-metric multidimensional scaling analysis (e.g., Grandy et al., 2009) after constructing a resemblance matrix using Euclidean distance from the percent abundance data.

\section{Results}

\subsection{RPO results}

All samples produced nearly identical thermograms (Fig. 1), suggesting that the activation energies assigned to the 1973 sample (Fig. A1) are applicable to samples from all four decades. Fractions 2 and 3 contained the greatest proportion of SOM, with the distribution across all five fractions being consistent between across all years (Table B1). A greater incorporation of the bomb spike in ${ }^{14} \mathrm{C}$ was found in the lowertemperature fractions, with no modern carbon seen in the highest-temperature fraction (Fig. 2). There was not enough $\mathrm{CO}_{2}$ for ${ }^{14} \mathrm{C}$ analysis of $\mathrm{F} 5$ in 1963 . The $\Delta{ }^{14} \mathrm{C}$ value for $\mathrm{F} 1$ in 1973 is included in Fig. 2 but removed from subsequent bomb-spike modeling.

\subsection{Bomb-spike turnover modeling results}

The single-pool steady-state model to trace the incorporation of the bomb spike in atmospheric ${ }^{14} \mathrm{CO}_{2}$ into the thermal fractions indicated that turnover times increased from 37 to 386 years with increasing temperature (Table 2). How-

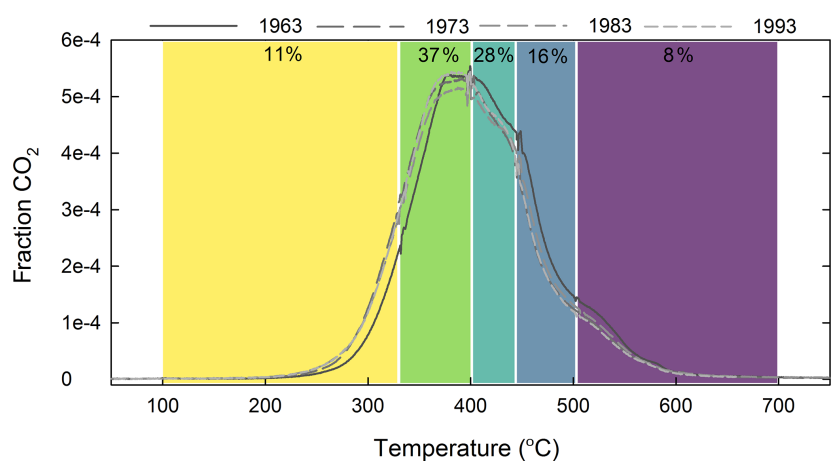

Figure 1. Proportion of total $\mathrm{CO}_{2}$ evolved with temperature as samples were oxidized with a ramp rate of $5^{\circ} \mathrm{Cmin}^{-1}$. Thermal fractions are shaded with colors corresponding to Figs. 2-4, and mean percent of total is given for each fraction.

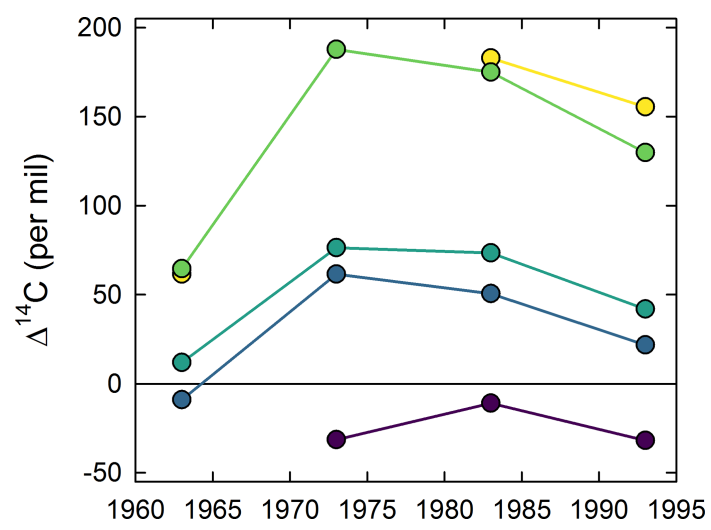

Figure 2. Variation in $\Delta^{14} \mathrm{C}$ in the five thermal fractions across the four decades of soil sampling. There was not enough $\mathrm{CO}_{2}$ for ${ }^{14} \mathrm{C}$ analysis of $\mathrm{F} 5$ in 1963. $\Delta^{14} \mathrm{C}$ value from $\mathrm{F} 1$ from 1973 not shown in (b) as this data point was removed as an outlier from the turnover modeling.

ever, with the exception of F5 a single-pool model resulted in unacceptably high error, with RMSE values ranging from $25 \%$ to $45 \%$ for the other fractions. Visually it was clear that the single-pool solution could not capture the dynamics of the increase and subsequent decrease in $\Delta^{14} \mathrm{C}$ in $\mathrm{F} 1-$ 
F4 (Fig. C1). A two-pool model with a fast-cycling pool ( $\tau=4$ years) and a variably sized slower-cycling pool was generally able to capture these dynamics with RMSE values below $13.8 \%$ (Table 2). With increasing activation energy of the thermal fraction, the proportion of fast-cycling carbon decreased (Fig. 3a) and the turnover time of the slow-cycling fraction increased (Fig. 3b).

As an independent first-order check on the reasonableness of the $\tau$ results for the thermal fractions, the inventoryweighted $\tau$ of the bulk soil was 16.5 years, matching the results of applying a three-pool turnover model to the bulk ${ }^{14} \mathrm{C}$ data, which varied from 11 to 20 years depending on the model structure (Sanderman et al., 2017).

\subsection{Py-GC/MS results}

A total of 172 individual compounds were identified in one or more samples. Many of these compounds were a minor fraction of only a single sample. When these compounds were classified by source, there were sharp differences in the dominant chemical compound classes released at each pyrolysis temperature (Fig. 4a). Lipids $(42.5 \pm 2.74 \%)$ and polysaccharides $(42.4 \pm 2.12 \%)$ were the dominant classes of compounds released at the lowest pyrolysis temperature $\left(330^{\circ} \mathrm{C}\right)$. Relative lipid abundance was $<10 \%$ of the pyrolysis products for all higher temperatures and $<1 \%$ relative abundance at the highest pyrolysis temperature $\left(735^{\circ} \mathrm{C}\right)$. Polysaccharides $(51.2 \pm 1.68 \%)$ remained an abundant component of the pyrolysis products at a pyrolysis temperature of $396^{\circ} \mathrm{C}$ and $444^{\circ} \mathrm{C}(27.4 \%)$ but were $<10 \%$ relative abundance at the two highest temperatures. At the fourth temperature level $\left(503{ }^{\circ} \mathrm{C}\right)$, N-bearing compounds, proteins, phenols and unknown compounds dominated the chemical signature and were all $\sim 15 \%-20 \%$ relative abundance. Phenols (31.4\%) were the most abundant compound class released at the highest temperature $\left(735^{\circ} \mathrm{C}\right)$, while proteins, aromatics and compounds of unknown origin were all $>15 \%$ relative abundance.

We identified 23 individual compounds that averaged more than one $1 \%$ relative abundance across all samples (Fig. 4b). These 23 compounds collectively represented from about $\sim 70 \%$ to $90 \%$ of the total sample relative abundance at the five different temperatures (Table D1). These compounds included three aromatic compounds, one lignin derivative, one lipid, two N-bearing compounds, two phenols, five polysaccharides, five proteins and four compounds that fell into the unknown origin. The most abundant compound was hexadecanoic acid methyl ester (palmitic acid) with a mean relative abundance across all samples of about $10 \%$ but composing $42 \%$ of F1 (Table D1). The next two most abundant compounds were both phenols and included phenol and 4-methyl phenol, both increasing with increasing temperature, followed by the common polysaccharide pyrolysis product furfural, primarily found in the lowertemperature fractions.

\section{Discussion}

While this study has only examined one soil under consistent management over four decades, the combined results from the modeling of the incorporation of bomb-spike ${ }^{14} \mathrm{CO}_{2}$ into thermal fractions and the stepped Py-GC/MS analysis here suggest that evolved gas analyses can be powerful analytical tools for understanding the complexities of SOM cycling. With increasing activation energy, turnover times increased from decades to centuries (Fig. 3), and there was a consistent (i.e., repeatable across time) strong shift in SOM chemistry (Fig. 4).

This investigation was partially framed in the context of testing evolved gas analysis as a tool for isolating biologically meaningful fractions of SOM. The results indicate that each of the five thermal fractions contained unique information. Each of the thermal fractions represented pools with a diverse mixture of organic materials with ${ }^{14} \mathrm{C}$-based turnover times ranging from 10 to 400 years. A wide distribution of activation energy (Fig. A1) was needed to describe each thermal fraction. Additionally, a one-pool turnover model could not represent the dynamics of ${ }^{14} \mathrm{C}$ in all but the most thermally stable fraction (Table 3 ). This finding of heterogeneity within an isolated fraction also plagues other physical and chemical techniques for isolating carbon fractions (Sanderman et al., 2013; Torn et al., 2013). Here, by combining ${ }^{14} \mathrm{C}$-based turnover modeling and compoundspecific chemical characterization of the thermal fractions, we have found clues as to reasons for the heterogeneity of SOM within these fractions which provide insights into pathways of SOM formation and longer-term stabilization.

At the two lowest-temperature intervals, where the ${ }^{14} \mathrm{C}$ data suggested rapid turnover rates, the polysaccharides comprised $>40 \%$ of the identified compounds. The dominant polysaccharide products at the two lowest temperatures included furfural, 3-furaldehyde and levoglucosenone. Furfural is a pyrolysis product of hexoses and pentoses as well as uronic acids. The hexoses originate from both plant and microbial residues, while the pentoses are primarily microbial in origin. Levoglucosenone is a pyrolysis product of neutral sugars such as glucose, galactose and mannose (SaizJimenez et al., 1979; Saiz-Jimenez and De Leeuw, 1986). These polysaccharides may be part of partially decomposed residues that dominate the light or particulate fractions of SOM or may be part of other soil carbon pools not strongly protected from thermal degradation by association with minerals. Across all thermal fractions, polysaccharide abundance was strongly correlated with the proportion of fast-cycling carbon in that fraction.

Identifiable lignin derivatives (e.g., syringol and guaiacol) were most abundant in the second and third thermal fractions but never constituted more than $10 \%$ of either thermal fraction. While the chemical complexity of lignin likely affords some thermal stability, as suggested by the greater activation energy than the thermal fraction dominated by polysaccha- 
Table 2. Results from bomb-spike soil carbon turnover modeling.

\begin{tabular}{lrrr|rrrrr}
\hline & & \multicolumn{6}{c}{ One-pool } & \multicolumn{5}{c}{ Two-pool } \\
\cline { 3 - 8 } Fraction & $E\left(\mathrm{~kJ} \mathrm{~mol}^{-1}\right)$ & $\tau(\mathrm{yrs})^{*}$ & $\mathrm{RMSE}$ & $f_{\text {fast }}$ & $f_{\text {slow }}$ & $\tau_{\text {fast }}(\mathrm{yrs})$ & $\tau_{\text {slow }}(\mathrm{yrs})$ & \multirow{2}{*}{$\mathrm{RMSE}$} \\
\hline F1 & 142.0 & 37.3 & 28.6 & 0.38 & 0.62 & 4.0 & 56.16 & 7.1 \\
F2 & 155.2 & 34.1 & 45.2 & 0.30 & 0.70 & 4.0 & 65.80 & 13.8 \\
F3 & 167.5 & 99.9 & 27.1 & 0.16 & 0.84 & 4.0 & 197.2 & 7.9 \\
F4 & 178.1 & 132.4 & 24.9 & 0.16 & 0.84 & 4.0 & 297.3 & 5.3 \\
F5 & 198.0 & 386.3 & 8.9 & 0.00 & 1.00 & 4.0 & 390.4 & 8.7 \\
\hline
\end{tabular}

* $\tau$ : turnover time.
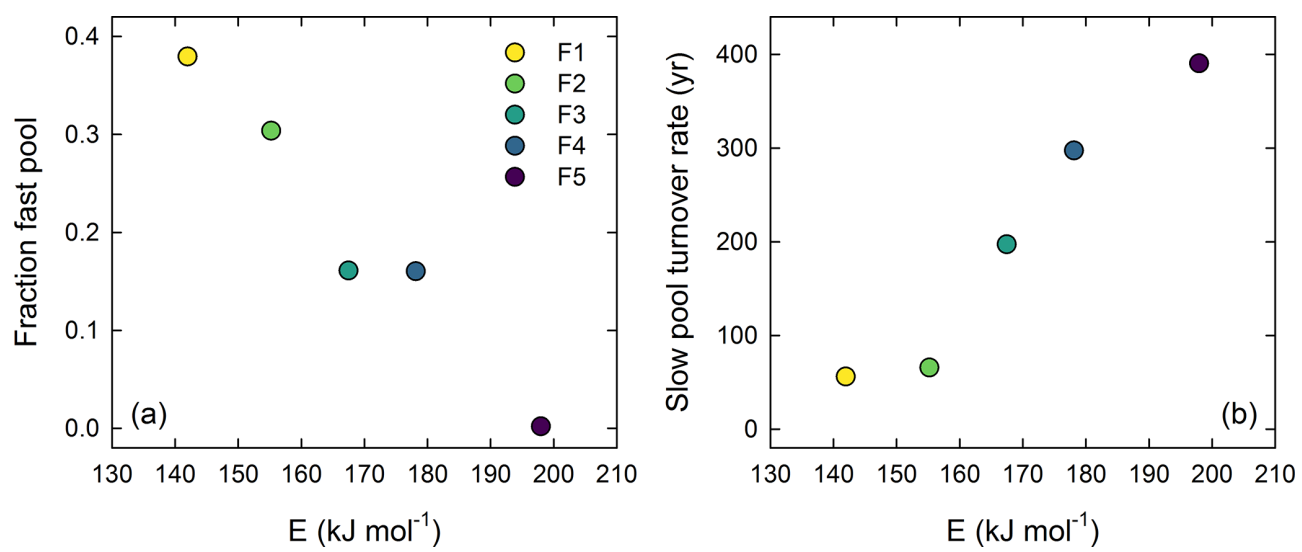

Figure 3. Two-pool ${ }^{14} \mathrm{C}$ modeling results: (a) proportion of fast-cycling carbon in thermal fraction and (b) turnover time $(\tau)$ of slow-cycling pool plotted as a function of mean activation energy of each thermal fraction.

rides, the ${ }^{14} \mathrm{C}$ data suggest that lignin is not a particularly persistent compound in this soil. This finding is consistent with past studies' findings that there is little recognizable lignin found in the more stable clay fractions of many soils (Baldock et al., 1997; Grandy and Neff, 2008; Schulten and Leinweber, 2000), although amounts may vary across different mineral types and environmental contexts (Kramer et al., 2012).

Besides polysaccharides, hexadecanoic acid methyl ester (palmitic acid) was the other dominant constituent of the lowest-temperature fraction (Table D1). This compound is a major constituent of microbial cell walls, especially fungi, and has been strongly correlated to both microbial biomass and activity (Zelles et al., 1992). The relative dominance of this lipid at low pyrolysis temperatures suggests that compared to other compounds it is not protected from degradation by association with either minerals or chemical complexity. There is a growing body of evidence suggesting that a substantial portion of stable SOM in many soils is microbial in origin (Kallenbach et al., 2015; Knicker, 2011; Miltner et al., 2012), which could lead to the misconception that microbial products are inherently more stable than plantderived compounds. The findings here suggest that palmitic acid, the most abundant lipid that we identified, which is most likely of microbial origin, is not a very thermally sta- ble component in soil with a much faster than average MRT. This may arise because these lipids are not forming direct covalent bonds with mineral surfaces nor are they forming other complexes (e.g., with metal oxides) that could make them resistant to thermal and biological degradation.

At the third- and fourth-highest temperatures, phenols, proteins and $\mathrm{N}$-bearing compounds became more relatively abundant. These phenols can originate not only from degraded lignin monomers but also other aromatics of plant or microbial origin. The proteins and other N-bearing compounds are important components of mineral-associated $\mathrm{N}$. The presence of heterocyclic $\mathrm{N}$ (e.g., furans, pyridines and pyrroles) is a common finding of studies using Py-GC/MS (Schulten and Schnitzer, 1997; Leinweber et al., 2014). Secondary chemical reactions in soil (de Assis et al., 2012) and wildfire (González-Pérez et al., 2004) as well as the pyrolysis process itself (Hatcher et al., 2001) are potential sources of heterocyclic N, but direct plant and microbial inputs also make a key contribution to this pool (Leinweber et al., 2014; Paul, 2016). The pyrazoles and pyridines, for example, may largely originate from microbes, and Kallenbach et al. (2016) found in an artificial soil system with only glucose inputs that a variety of heterocyclic $\mathrm{N}$ compounds can be derived from the pyrolysis of microbial cells. 

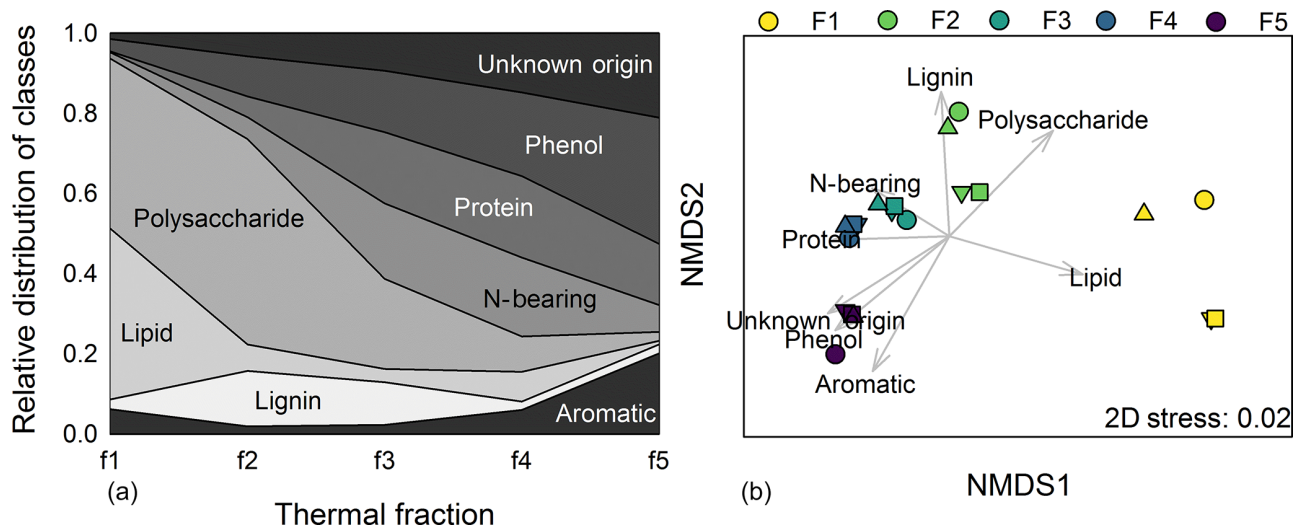

Figure 4. Stepped pyrolysis-gas chromatography-mass spectrometry results: (a) mean distribution of major compound classes across the four years; (b) Non-metric multidimensional scaling plot of all compounds with $>1 \%$ mean abundance $(n=23)$. In (b) vectors represent

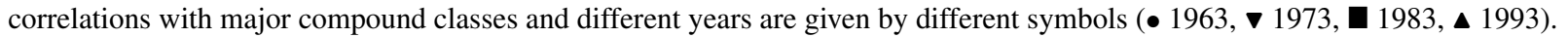

We have previously found that polysaccharides, proteins and N-bearing compounds are the dominant mineralassociated chemical fractions (Grandy et al., 2007; Grandy and Neff, 2008) as well as comprising an increasing proportion of these compounds with soil depth (Rothstein et al., 2018). Anticipating that these same compounds would also dominate the slowest-cycling highest-temperature fraction, we found that aromatic compounds and compounds from an unknown source, which included compounds such as toluene, the eleventh-most-abundant compound, which may be derived from pyrolyzing aromatics or proteins, were relatively abundant. There have been reports that pyrolysis of clay fractions can produce matrix effects that inflate the abundance of aromatic compounds (Schulten and Leinweber, 1993). We have seen no detectable evidence for this in our previous studies, which generally show very low abundance of aromatics in fine fractions. The relatively low clay content and dominance of illite in our soils also point to lower potential for matrix effects. More likely, the high relative abundance of stable aromatics, phenols and compounds of unknown origin can be attributed to the history of fire at this Mediterranean site. Previous studies at the site indicate that $\sim 30 \%$ of the total SOM is made up of pyrogenic aromatics (Sanderman et al., 2017).

A potential limitation of this study was that we could not determine if the thermal fractions isolated for ${ }^{14} \mathrm{C}$ analysis corresponded precisely with the stepped Py-GC/MS data. Grant et al. (2019) demonstrated that for soil samples there was minimal difference in the shape of evolved $\mathrm{CO}_{2}$ between ramped oxidation and ramped pyrolysis on the NOSAMS RPO instrumentation, but it is difficult to quantify the carbon mass evolved through the Py-GC/MS. Future research coupling the stepped pyrolysis front end with an oxidizing oven and subsequent $\mathrm{CO}_{2}$ measurement is necessary to alleviate this uncertainty.
The findings from this preliminary investigation add to the growing body of literature using evolved gas analysis as a tool for understanding SOM dynamics. The two unique aspects of this work were using a time series of soil samples to calculate the MRT of different thermal fractions and relating these MRTs to the chemical composition of each fraction. We found that mean residence time increased with increasing activation energy. Modeling the incorporation of the bomb spike in ${ }^{14} \mathrm{CO}_{2}$ indicated that the thermal fractions were, except for the most stable fraction, heterogeneous mixtures of fast- and slow- cycling SOM. Compound-specific analysis demonstrated that distinct assemblages of organic compounds were found with increasing thermal stability. These findings together suggest similar thermal activation energies may not equate to similar biological accessibility of the same material, and care needs to be taken not to overinterpret results from thermal analysis alone. Important follow-up work includes analyzing just the mineral-associated OM fraction to better understand this potential disconnect between thermal and biological stability. By coupling evolved gas analysis with radiocarbon and compound-specific chemical analyses, new insights into the formation, stabilization and fate of SOM may be possible. 


\section{Appendix A}

Following acquisition of an initial thermogram (i.e., the trend of $\mathrm{CO}_{2}$ evolution versus increasing temperature) for the 1973 sample, a mathematical inversion method was employed to deconvolve the evolved gas analysis into $N$ number of pools with distinct activation energy profiles (Hemingway et al., 2017a).

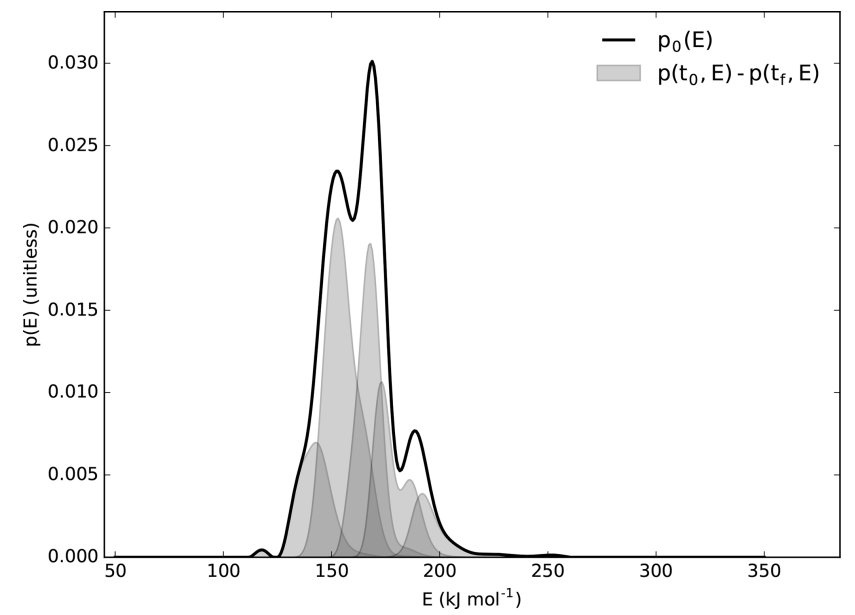

Figure A1. Proportion of activation energy $(E)$ found with increasing activation energy. Distribution of $E$ within each RPO fraction given by shaded regions.

Table A1. Thermal fraction activation energies and distribution (SD: standard deviation) based on inversion analysis.

\begin{tabular}{lrrr}
\hline Fraction & $T_{0}\left({ }^{\circ} \mathrm{C}\right)$ & $E\left(\mathrm{~kJ} \mathrm{~mol}^{-1}\right)$ & $\mathrm{SD}$ \\
\hline 1 & 100 & 141.96 & 8.21 \\
2 & 325 & 155.21 & 7.76 \\
3 & 400 & 167.47 & 5.98 \\
4 & 445 & 178.13 & 8.00 \\
5 & 515 & 197.95 & 13.24 \\
\hline
\end{tabular}


Appendix B

Table B1. Ramped oxidation isotope results.

\begin{tabular}{rlllrrrr}
\hline Year & Fraction & Frac. of total $C^{*}$ & NOSAMS accession \# & $F$ modern & $F$ modern Error & $\delta^{13} \mathrm{C}(\% \circ)$ & $\Delta^{14} \mathrm{C}(\% o)$ \\
\hline 1963 & 1 & 0.08 & OS-131571 & 1.0632 & 0.0023 & n.d. & 61.5 \\
& 2 & 0.34 & OS-131374 & 1.0662 & 0.0021 & -27.97 & 64.5 \\
& 3 & 0.30 & OS-131504 & 1.0135 & 0.0020 & -26.49 & 11.9 \\
& 4 & 0.18 & OS-131505 & 0.9926 & 0.0021 & -26.65 & -9.0 \\
& 5 & 0.10 & no sample & & & & \\
\hline 1973 & 1 & 0.11 & OS-131506 & 0.9754 & 0.0033 & -30.00 & -27.3 \\
& 2 & 0.41 & OS-131375 & 1.1910 & 0.0024 & -27.08 & 187.7 \\
& 3 & 0.26 & OS-131507 & 1.0793 & 0.0044 & -26.17 & 76.3 \\
& 4 & 0.16 & OS-131508 & 1.0645 & 0.0021 & -25.22 & 61.5 \\
& 5 & 0.07 & OS-131574 & 0.9713 & 0.0026 & -25.53 & -31.4 \\
\hline 1983 & 1 & 0.11 & OS-131509 & 1.1876 & 0.0026 & -29.58 & 182.9 \\
& 2 & 0.37 & OS-131376 & 1.1796 & 0.0023 & -27.43 & 174.9 \\
& 3 & 0.28 & OS-131377 & 1.0777 & 0.0026 & -26.27 & 73.4 \\
& 4 & 0.17 & OS-131510 & 1.0548 & 0.0022 & -25.93 & 50.6 \\
& 5 & 0.07 & OS-131573 & 0.9930 & 0.0026 & -26.39 & -11.0 \\
\hline 1993 & 1 & 0.14 & OS-131511 & 1.1615 & 0.0024 & -28.87 & 155.5 \\
& 2 & 0.36 & OS-131378 & 1.1357 & 0.0025 & -27.17 & 129.8 \\
& 3 & 0.28 & OS-131707 & 1.0473 & 0.0027 & -26.06 & 41.9 \\
4 & 0.15 & OS-131708 & 1.0271 & 0.0020 & -25.97 & 21.8 \\
5 & 0.07 & OS-131783 & 0.9732 & 0.0024 & -25.64 & -31.8 \\
\hline
\end{tabular}

* Proportion of total $p \mathrm{CO}_{2}$ found in each thermal split (i.e., fraction). 


\section{Appendix C}

Bomb-spike turnover modeling results for one-pool and twopool models.
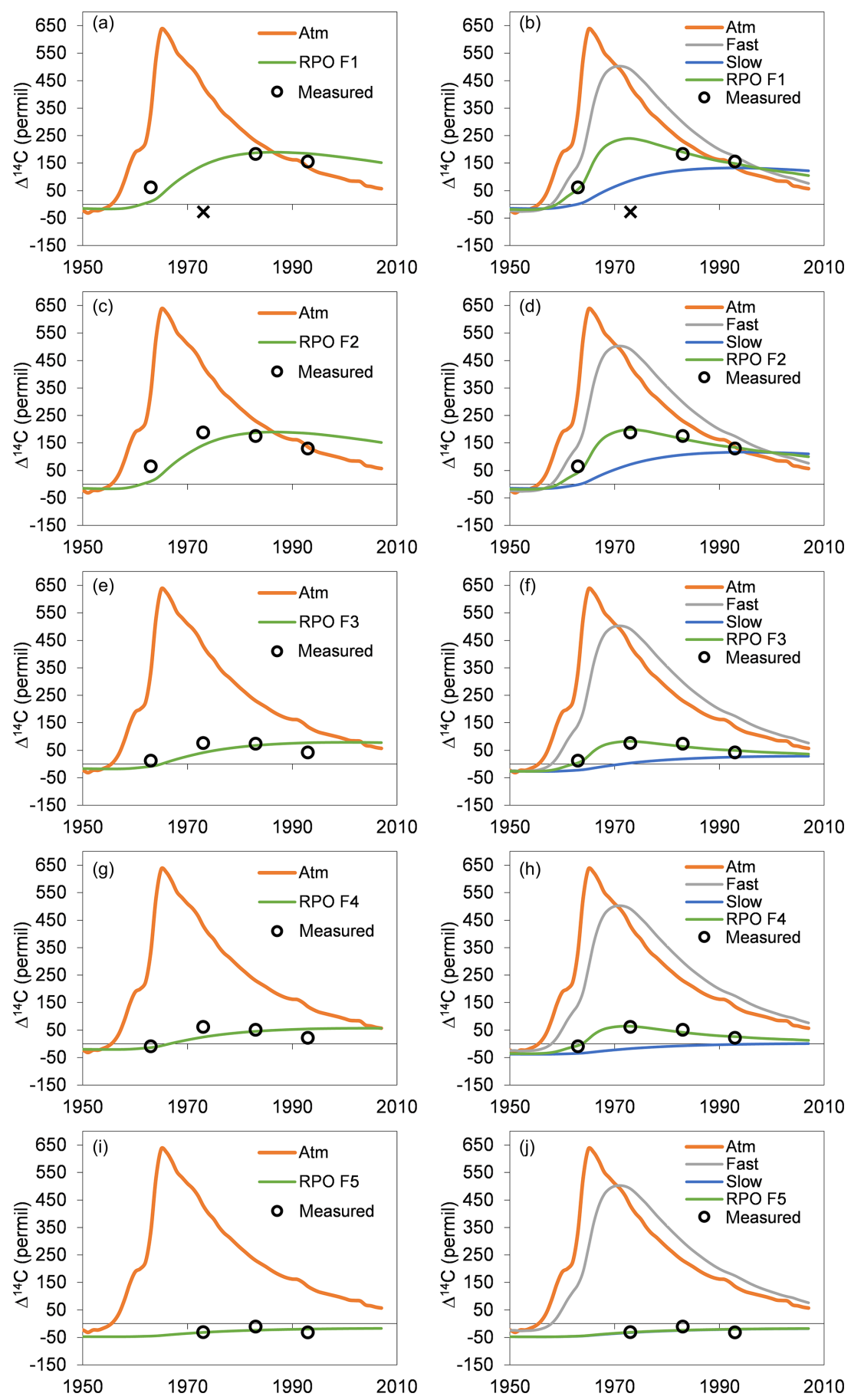

Figure C1. One-pool (a, $\mathbf{c}, \mathbf{e}, \mathbf{g}, \mathbf{i})$ and two-pool $(\mathbf{b}, \mathbf{d}, \mathbf{f}, \mathbf{h}, \mathbf{j})$ solutions to a steady-state soil carbon turnover model for the five thermal fractions. Southern Hemisphere atmospheric record given in the background of each panel. For two-pool solutions the trend in $\Delta^{14} \mathrm{C}$ is given for the fast and slow pools as well as the overall thermal fraction. The $\mathrm{X}$ in panels (a) and (b) refers to the $\Delta^{14} \mathrm{C}$ measurement deemed to be an outlier for purposes of bomb-spike modeling. 
Appendix D

Table D1. Most abundant compound classes (mean across years) identified by stepped Py-GC/MS.

\begin{tabular}{|c|c|c|c|c|c|c|}
\hline Compound & Source & $\mathrm{F} 1$ & $\mathrm{~F} 2$ & F3 & F4 & F5 \\
\hline Phenol, 3,4-dimethyl- & Aromatic & 0.3 & 0.8 & 1.5 & 2.6 & 2.0 \\
\hline Fluorene & Aromatic & 0.0 & 0.0 & 0.0 & 0.3 & 6.0 \\
\hline Naphthalene & Aromatic & 0.0 & 0.0 & 0.0 & 0.8 & 5.0 \\
\hline Phenol, 2-methoxy- (guaiacol) & Lignin & 0.9 & 6.1 & 5.4 & 1.0 & 0.0 \\
\hline Hexadecanoic acid, methyl ester (palmitic acid-C16) & Lipid & 41.5 & 4.9 & 3.1 & 0.4 & 0.0 \\
\hline Pyrazolo[5,1-c] $[1,2,4]$ benzotriazin-8-ol & N-bearing & 0.0 & 1.3 & 11.7 & 13.0 & 1.2 \\
\hline 1H-Pyrrole, 3-methyl- & N-bearing & 0.0 & 0.9 & 1.9 & 2.5 & 0.6 \\
\hline Phenol & Phenol & 1.0 & 6.9 & 9.1 & 10.5 & 16.7 \\
\hline Phenol, 4-methyl- & Phenol & 2.1 & 3.1 & 6.2 & 10.3 & 14.6 \\
\hline Furfural & Polysaccharide & 16.0 & 13.4 & 4.1 & 0.2 & 0.0 \\
\hline 3-Furaldehyde & Polysaccharide & 10.2 & 8.3 & 0.9 & 0.0 & 0.0 \\
\hline Levoglucosenone & Polysaccharide & 9.0 & 9.2 & 1.1 & 0.0 & 0.0 \\
\hline Benzofuran, 2,3-dihydro- & Polysaccharide & 0.9 & 7.3 & 6.0 & 2.2 & 1.1 \\
\hline Furfural, 5-methyl- & Polysaccharide & 5.7 & 7.8 & 3.1 & 0.5 & 0.0 \\
\hline Indole & Protein & 0.2 & 2.5 & 5.0 & 3.7 & 4.1 \\
\hline Pyrrole & Protein & 0.0 & 1.0 & 3.3 & 3.4 & 0.4 \\
\hline Benzyl nitrile & Protein & 0.0 & 0.5 & 3.0 & 3.4 & 0.3 \\
\hline 3-Methylindole & Protein & 0.0 & 0.4 & 1.5 & 2.3 & 2.8 \\
\hline Styrene & Protein & 0.0 & 0.0 & 0.9 & 3.6 & 2.2 \\
\hline Toluene & Unknown origin & 0.0 & 0.5 & 2.2 & 5.8 & 5.9 \\
\hline 1,3,5-Cycloheptatriene & Unknown origin & 0.4 & 2.8 & 3.4 & 0.7 & 0.0 \\
\hline Phenanthrene & Unknown origin & 0.1 & 0.0 & 0.0 & 0.1 & 6.9 \\
\hline Monobenzone & Unknown origin & 0.0 & 0.9 & 2.6 & 2.2 & 0.0 \\
\hline$\%$ of all compound abundance & & 88.2 & 78.4 & 76.1 & 69.6 & 69.7 \\
\hline
\end{tabular}


Data availability. Data from the Waite Permanent Rotation Trial are available for download from the CSIRO Data Access Portal (https://doi.org/10.4225/08/55E5165EC0D29, Sanderman et al., 2015). Radiocarbon and Py-GC/MS data are given in Appendices B and D.

Author contributions. JS conceived the study. JS carried out radiocarbon measurements and interpretation. ASG carried out PyGC/MS measurements and interpretation. JS and ASG contributed equally to manuscript preparation.

Competing interests. The authors declare that they have no conflict of interest.

Acknowledgements. We thank NOSAMS director Mark KurZ for providing in-kind support for ${ }^{13} \mathrm{C}$ and ${ }^{14} \mathrm{C}$ analysis of the samples in this study. We would also like to extend our thanks to Ann McNichol and Mary Lardie for assistance and training in operating the Dirt Burner and Jordon Hemingway for running the activation energy inversion model. Finally, we thank the numerous researchers at the Waite Institute for having the foresight to archive soil samples from the long-term experiment.

Review statement. This paper was edited by Steven Sleutel and reviewed by two anonymous referees.

\section{References}

Baisden, W. T., Parfitt, R. L., Ross, C., Schipper, L. A., and Canessa, S.: Evaluating 50 years of time-series soil radiocarbon data: Towards routine calculation of robust $\mathrm{C}$ residence times, Biogeochemistry, 112, 129-137, https://doi.org/10.1007/s10533011-9675-y, 2013.

Baldock, J. A., Oades, J. M., Nelson, P. N., Skene, T. M., Golchin, A., and Clarke, P.: Assessing the extent of decomposition of natural organic materials using solid-state 13C NMR spectroscopy, Aust. J. Soil Res., 35, 1061-1084, 1997.

Baldock, J. A., Sanderman, J., Macdonald, L. M., Puccini, A., Hawke, B. A., Szarvas, S., and Mcgowan, J.: Quantifying the allocation of soil organic carbon to biologically significant fractions, Soil Res., 51, 561-576, 2013.

Buurman, P., Peterse, F., and Almendros Martin, G.: Soil organic matter chemistry in allophanic soils: a pyrolysis-GC/MS study of a Costa Rican Andosol catena, Eur. J. Soil Sci., 58, 1330-1347, 2007.

Cécillon, L., Baudin, F., Chenu, C., Houot, S., Jolivet, R., Kätterer, T., Lutfalla, S., Macdonald, A., van Oort, F., Plante, A. F., Savignac, F., Soucémarianadin, L. N., and Barré, P.: A model based on Rock-Eval thermal analysis to quantify the size of the centennially persistent organic carbon pool in temperate soils, Biogeosciences, 15, 2835-2849, https://doi.org/10.5194/bg-152835-2018, 2018.
Christensen, B. T.: Physical fractionation of soil and structural and functional complexity in organic matter turnover, Eur. J. Soil Sci., 52, 345-353, 2001.

Cotrufo, M. F., Wallenstein, M. D., Boot, C. M., Denef, K., and Paul, E.: The Microbial Efficiency-Matrix Stabilization (MEMS) framework integrates plant litter decomposition with soil organic matter stabilization: do labile plant inputs form stable soil organic matter?, Glob. Change Biol., 19, 988-995, https://doi.org/10.1111/gcb.12113, 2013.

Currie, K. I., Brailsford, G., Nichol, S., Gomez, A., Sparks, R., Lassey, K. R., and Riedel, K.: Tropospheric ${ }^{14} \mathrm{CO}_{2}$ at Wellington, New Zealand: the world's longest record, Biogeochemistry, 104, 5-22, 2011.

de Assis, C. P., González-Pérez, J. A., de la Rosa, J. M., Jucksch, I., Mendonça, E. de S., and González-Vila, F. J.: Analytical pyrolysis of humic substances from a Latosol (Typic Hapludox) under different land uses in Minas Gerais, Brazil, J. Anal. Appl. Pyrol., 93, 120-128, https://doi.org/10.1016/J.JAAP.2011.10.005, 2012.

Elliott, E. T. and Cambardella, C. A.: Physical separation of soil organic matter, Agr. Ecosyst. Environ., 34, 407-419, 1991.

Golchin, A., Oades, J. M., Skjemstad, J. O., and Clarke, P.: Soil structure and carbon cycling, Soil Res., 32, 1043-1068, 1994.

González-Pérez, J. A., González-Vila, F. J., Almendros, G., and Knicker, H.: The effect of fire on soil organic mattera review, Environ. Int., 30, 855-870, https://doi.org/10.1016/J.ENVINT.2004.02.003, 2004.

Grace, P., Oades, J., Keith, H., and Hancock, T.: Trends in wheat yields and soil organic carbon in the Permanent Rotation Trial at the Waite Agricultural Research Institute, South Australia, Aust. J. Exp. Agr., 35, 857, https://doi.org/10.1071/EA9950857, 1995.

Grandy, A. S. and Neff, J. C.: Molecular C dynamics downstream: the biochemical decomposition sequence and its impact on on soil organic matter structure and function, Sci. Total Environ., 404, 221-446, 2008.

Grandy, A. S. and Robertson, G. P.: Land-Use Intensity Effects on Soil Organic Carbon Accumulation Rates and Mechanisms, Ecosystems, 10, 59-74, https://doi.org/10.1007/s10021006-9010-y, 2007.

Grandy, A. S., Neff, J. C., and Weintraub, M. N.: Carbon structure and enzyme activities in alpine and forest ecosystems, Soil Biol. Biochem., 39, 2701-2711, https://doi.org/10.1016/J.SOILBIO.2007.05.009, 2007.

Grandy, A. S., Strickland, M. S., Lauber, C. L., Bradford, M. A., and Fierer, N.: The influence of microbial communities, management, and soil texture on soil organic matter chemistry, Geoderma, 150, 278-286, 2009.

Grant, K. E., Galy, V. V., Chadwick, O. A., and Derry, L. A.: Thermal oxidation of carbon in organic matter rich volcanic soils: insights into SOC age differentiation and mineral stabilization, Biogeochemistry, 144, 291-304, https://doi.org/10.1007/s10533019-00586-1, 2019.

Hatcher, P. G., Dria, K. J., Kim, S., and Frazier, S. W.: Modern analytical studies of humic substances, Soil Sci., 166, 770-794, 2001.

Helfrich, M., Flessa, H., Dreves, A., and Ludwig, B.: Is thermal oxidation at different temperatures suitable to isolate soil organic carbon fractions with different turnover?, J. Plant Nutr. Soil Sc., 173, 61-66, 2010. 
Hemingway, J. D., Rothman, D. H., Rosengard, S. Z., and Galy, V. V.: Technical note: An inverse method to relate organic carbon reactivity to isotope composition from serial oxidation, Biogeosciences, 14, 5099-5114, https://doi.org/10.5194/bg-145099-2017, 2017a.

Hemingway, J. D., Galy, V. V., Gagnon, A. R., Grant, K. E., Rosengard, S. Z., Soulet, G., Zigah, P. K., and McNichol, A. P.: Assessing the blank carbon contribution, isotope mass balance, and kinetic isotope fractionation of the ramped pyrolysis/oxidation instrument at NOSAMS, Radiocarbon, 59, 179-193, 2017b.

Hempfling, R. and Schulten, H.-R.: Chemical characterization of the organic matter in forest soils by Curie point pyrolysisGC/MS and pyrolysis-field ionization mass spectrometry, Org. Geochem., 15, 131-145, 1990.

IUSS Working Group WRB: World Reference Base for Soil Resources 2014, update 2015, International soil classification system for naming soils and creating legends for soil maps, World Soil Resources Reports No. 106. FAO, Rome, 2015.

Jastrow, J. D., Miller, R. M., and Boutton, T. W.: Carbon dynamics of aggregate-associated organic matter estimated by carbon-13 natural abundance, Soil Sci. Soc. Am. J., 60, 801-807, 1996.

Kallenbach, C. M., Grandy, A. S., Frey, S. D., and Diefendorf, A. F.: Microbial physiology and necromass regulate agricultural soil carbon accumulation, Soil Biol. Biochem., 91, 279-290, https://doi.org/10.1016/j.soilbio.2015.09.005, 2015.

Kallenbach, C. M., Frey, S. D., and Grandy, A. S.: Direct evidence for microbial-derived soil organic matter formation and its ecophysiological controls, Nat. Commun., 7, 13630, https://doi.org//10.1038/ncomms13630, 2016.

Knicker, H.: Soil organic N - An under-rated player for C sequestration in soils?, Soil Biol. Biochem., 43, 1118-1129, https://doi.org/10.1016/j.soilbio.2011.02.020, 2011.

Kramer, M. G., Sanderman, J., Chadwick, O. A., Chorover, J., and Vitousek, P. M.: Long-term carbon storage through retention of dissolved aromatic acids by reactive particles in soil, Glob. Change Biol., 18, 2594-2605, https://doi.org/10.1111/j.13652486.2012.02681.x, 2012.

Lehmann, J. and Kleber, M.: The contentious nature of soil organic matter, Nature, 528, 60-68, https://doi.org/10.1038/nature16069, 2015.

Leinweber, P., Kruse, J., Baum, C., Arcand, M., Knight, J. D., Farrell, R., Eckhardt, K.-U., Kiersch, K., and Jandl, G.: Chapter Two - Advances in Understanding Organic Nitrogen Chemistry in Soils Using State-of-the-art Analytical Techniques, Advances in Agronomy, Academic Press, Volume 119, 83-151, 2013.

Lopez-Capel, E., Sohi, S. P., Gaunt, J. L., and Manning, D. A. C.: Use of thermogravimetry-differential scanning calorimetry to characterize modelable soil organic matter fractions, Soil Sci. Soc. Am. J., 69, 136-140, 2005.

Manzoni, S. and Porporato, A.: Soil carbon and nitrogen mineralization: Theory and models across scales, Soil Biol. Biochem., 41, 1355-1379, https://doi.org/10.1016/j.soilbio.2009.02.031, 2009.

McNichol, A. P., Jones, G. A., Hutton, D. L., Gagnon, A. R., and Key, R. M.: The rapid preparation of seawater ${ }^{14} \mathrm{CO}_{2}$ for radiocarbon analysis at the National Ocean Sciences AMS facility, Radiocarbon, 36, 237-246, 1994a.

McNichol, A. P., Osborne, E. A., Gagnon, A. R., Fry, B., and Jones, G. A.: TIC, TOC, DIC, DOC, PIC, POC unique aspects in the preparation of oceanographic samples for ${ }^{14} \mathrm{C}$-AMS, Nucl. Instrum. Meth. B, 92, 162-165, 1994b.

Miltner, A., Bombach, P., Schmidt-Brücken, B., and Kästner, M.: SOM genesis: Microbial biomass as a significant source, Biogeochemistry, 111, 41-55, https://doi.org/10.1007/s10533-0119658-z, 2012.

Paul, E. A.: The nature and dynamics of soil organic matter: Plant inputs, microbial transformations, and organic matter stabilization, Soil Biol. Biochem., 98, 109-126, https://doi.org/10.1016/j.soilbio.2016.04.001, 2016.

Paul, E. A., Collins, H. P., and Leavitt, S. W.: Dynamics of resistant soil carbon of Midwestern agricultural soils measured by naturally occurring ${ }^{14} \mathrm{C}$ abundance, Geoderma, 104, 239-256, 2001.

Peltre, C., Fernández, J. M., Craine, J. M., and Plante, A. F.: Relationships between Biological and Thermal Indices of Soil Organic Matter Stability Differ with Soil Organic Carbon Level, Soil Sci. Soc. Am. J., 77, 2020, https://doi.org/10.2136/sssaj2013.02.0081, 2013.

Plante, A. F., Fernández, J. M., and Leifeld, J.: Application of thermal analysis techniques in soil science, Geoderma, 153, 1-10, https://doi.org/10.1016/j.geoderma.2009.08.016, 2009.

Plante, A. F., Beaupré, S. R., Roberts, M. L., and Baisden, T.: Distribution of radiocarbon ages in soil organic matter by thermal fractionation, Radiocarbon, 55, 1077-1083, 2013.

Poeplau, C., Don, A., Six, J., Kaiser, M., Benbi, D., Chenu, C., Cotrufo, M. F., Derrien, D., Gioacchini, P., Grand, S., Gregorich, E., Griepentrog, M., Gunina, A., Haddix, M., Kuzyakov, Y., Kuhnel, A., Macdonald, L. M., Soong, J., Trigalet, S., Vermeire, M.L., Rovira, P., van Wesemael, B., Wiesmeier, M., Yeasmin, S., Yevdokimov, I., and Nieder, R.: Isolating organic carbon fractions with varying turnover rates in temperate agricultural soilsA comprehensive method comparison, Soil Biol. Biochem., 125, 10-26, 2018.

Rosenheim, B. E., Day, M. B., Domack, E., Schrum, H., Benthien, A., and Hayes, J. M.: Antarctic sediment chronology by programmed-temperature pyrolysis: Methodology and data treatment, Geochem. Geophy. Geosy., 9, Q04005, https://doi.org/10.1029/2007GC001816, 2008.

Rothstein, D. E., Toosi, E. R., Schaetzl, R. J., and Grandy, A. S.: Translocation of Carbon from Surface Organic Horizons to the Subsoil in Coarse-Textured Spodosols: Implications for Deep Soil C Dynamics, Soil Sci. Soc. Am. J., 82, 969-982, https://doi.org/10.2136/sssaj2018.01.0033, 2018.

Rovira, P., Kurz-Besson, C., Coûteaux, M.-M., and Ramón Vallejo, V.: Changes in litter properties during decomposition: A study by differential thermogravimetry and scanning calorimetry, Soil Biol. Biochem., 40, 172-185, https://doi.org/10.1016/j.soilbio.2007.07.021, 2008.

Ruamps, L. S., Nunan, N., Pouteau, V., Leloup, J., Raynaud, X., Roy, V., and Chenu, C.: Regulation of soil organic C mineralisation at the pore scale, FEMS Microbiol. Ecol., 86, 26-35, https://doi.org/10.1111/1574-6941.12078, 2013.

Saiz-Jimenez, C. and De Leeuw, J. W.: Chemical characterization of soil organic matter fractions by analytical pyrolysis-gas chromatography-mass spectrometry, J. Anal. Appl. Pyrol., 9, 99119, https://doi.org/10.1016/0165-2370(86)85002-1, 1986.

Saiz-Jimenez, C., Haider, K., and Meuzelaar, H. L. C.: Comparisons of soil organic matter and its fractions 
by pyrolysis mass-spectrometry, Geoderma, 22, 25-37, https://doi.org/10.1016/0016-7061(79)90037-5, 1979.

Sanderman, J., Fillery, I. R. P., Jongepier, R., Massalsky, A., Roper, M. M., MacDonald, L. M., Maddern, T., Murphy, D. V., and Baldock, J. A.: Carbon sequestration under subtropical perennial pastures II: Carbon dynamics, Soil Res., 51, 771-780, https://doi.org/10.1071/SR12351, 2013.

Sanderman, J., Rakesh, D., Moore, A., Keith, H., Farquharson, R.: Waite Permanent Rotation Trial. v4. CSIRO, Data Collection, https://doi.org/10.4225/08/55E5165EC0D29, 2015.

Sanderman, J., Baisden, W. T., and Fallon, S.: Redefining the inert organic carbon pool, Soil Biol. Biochem., 92, 149-152, https://doi.org/10.1016/j.soilbio.2015.10.005, 2016.

Sanderman, J., Creamer, C., Baisden, W. T., Farrell, M., and Fallon, S.: Greater soil carbon stocks and faster turnover rates with increasing agricultural productivity, SOIL, 3, 1-16, https://doi.org/10.5194/soil-3-1-2017, 2017.

Schädel, C., Luo, Y., Evans, R. D., Fei, S., and Schaeffer, S. M.: Separating soil $\mathrm{CO}_{2}$ efflux into C-pool-specific decay rates via inverse analysis of soil incubation data, Oecologia, 171, 721732, 2013.

Schiedung, M., Don, A., Wordell-Dietrich, P., Alcántara, V., Kuner, P., and Guggenberger, G.: Thermal oxidation does not fractionate soil organic carbon with differing biological stabilities, J. Plant Nutr. Soil Sc., 180, 18-26, 2017.

Schmidt, M. W. I., Torn, M. S., Abiven, S., Dittmar, T., Guggenberger, G., Janssens, I. A., Kleber, M., Kögel-Knabner, I., Lehmann, J., Manning, D. A. C., Nannipieri, P., Rasse, D. P., Weiner, S., and Trumbore, S. E.: Persistence of soil organic matter as an ecosystem property, Nature, 478, 49-56, https://doi.org/10.1038/nature10386, 2011.

Schulten, H.-R. and Leinweber, P.: Pyrolysis-field ionization mass spectrometry of agricultural soils and humic substances: Effect of cropping systems and influence of the mineral matrix, Plant Soil, 151, 77-90, 1993.

Schulten, H.-R. and Leinweber, P.: New insights into organicmineral particles: composition, properties and models of molecular structure, Biol. Fert. Soils, 30, 399-432, https://doi.org/10.1007/s003740050020, 2000.

Schulten, H. R. and Schnitzer, M.: The chemistry of soil organic nitrogen: a review, Biol. Fert. Soils, 26, 1-15, https://doi.org/10.1007/s003740050335, 1997.

Skjemstad, J. O., Spouncer, L. R., Cowie, B., and Swift, R. S.: Calibration of the Rothamsted organic carbon turnover model (RothC ver. 26.3), using measurable soil organic carbon pools, Aust. J. Soil Res., 42, 79-88, https://doi.org/10.1071/SR03013, 2004.

Sokol, N. W., Sanderman, J., and Bradford, M. A.: Pathways of mineral-associated soil organic matter formation: Integrating the role of plant carbon source, chemistry, and point of entry, Glob. Change Biol., 25, 12-24, 2019.

Soil Survey Staff: Soil taxonomy: A basic system of soil classification for making and interpreting soil surveys, 2nd edition, Natural Resources Conservation Service, U.S. Department of Agriculture Handbook 436, 1999.

Sollins, P., Kramer, M. G., Swanston, C., Lajtha, K., Filley, T., Aufdenkampe, A. K., Wagai, R., and Bowden, R. D.: Sequential density fractionation across soils of contrasting mineralogy: evidence for both microbial- and mineral-controlled soil organic matter stabilization, Biogeochemistry, 96, 209-231, https://doi.org/10.1007/s10533-009-9359-z, 2009.

Soucémarianadin, L., Cécillon, L., Chenu, C., Baudin, F., Nicolas, M., Girardin, C., and Barré, P.: Is Rock-Eval 6 thermal analysis a good indicator of soil organic carbon lability?-A methodcomparison study in forest soils, Soil Biol. Biochem., 117, 108116, 2018.

Stuiver, M. and Polach, H. A.: Discussion reporting of ${ }^{14} \mathrm{C}$ data, Radiocarbon, 19, 355-363, 1977.

Torn, M. S., Kleber, M., Zavaleta, E. S., Zhu, B., Field, C. B., and Trumbore, S. E.: A dual isotope approach to isolate soil carbon pools of different turnover times, Biogeosciences, 10, 80678081, https://doi.org/10.5194/bg-10-8067-2013, 2013.

Trumbore, S.: Radiocarbon and soil carbon dynamics, Annu. Rev. Earth Pl. Sc., 37, 47-66, 2009.

Trumbore, S. E., Chadwick, O. A., and Amundson, R.: Rapid exchange between soil carbon and atmospheric carbon dioxide driven by temperature change, Science, 272, 393-396, https://doi.org/10.1126/science.272.5260.393, 1996.

von Lützow, M., Kögel-Knabner, I., Ekschmitt, K., Flessa, H., Guggenberger, G., Matzner, E., and Marschner, B.: SOM fractionation methods: Relevance to functional pools and to stabilization mechanisms, Soil Biol. Biochem., 39, 2183-2207, https://doi.org/10.1016/j.soilbio.2007.03.007, 2007.

Wickings, K., Grandy, A. S., Reed, S., and Cleveland, C.: Management intensity alters decomposition via biological pathways, Biogeochemistry, 104, 365-379, https://doi.org/10.1007/s10533010-9510-x, 2011.

Williams, E. K. and Plante, A. F.: A bioenergetic framework for assessing soil organic matter persistence, Front. Earth Sci., 6, 143, https://doi.org/10.3389/feart.2018.00143, 2018.

Williams, E. K., Rosenheim, B. E., McNichol, A. P., and Masiello, C. A.: Charring and non-additive chemical reactions during ramped pyrolysis: Applications to the characterization of sedimentary and soil organic material, Org. Geochem., 77, 106-114, 2014.

Williams, E. K., Fogel, M. L., Berhe, A. A., and Plante, A. F.: Distinct bioenergetic signatures in particulate versus mineralassociated soil organic matter, Geoderma, 330, 107-116, 2018.

Yang, H., Yan, R., Chen, H., Zheng, C., Lee, D. H., and Liang, D. T.: In-depth investigation of biomass pyrolysis based on three major components: hemicellulose, cellulose and lignin, Energ. Fuel., 20, 388-393, 2006.

Zelles, L., Bai, Q. Y., Beck, T., and Beese, F.: Signature fatty-acids in phospholipids and lipopolysaccharides as indicators of microbial biomass and community structure in agricultural soils, Soil Biol. Biochem., 24, 317-323, https://doi.org/10.1016/00380717(92)90191-y, 1992.

Zimmermann, M., Leifeld, J., Schmidt, M. W. I., Smith, P., and Fuhrer, J.: Measured soil organic matter fractions can be related to pools in the RothC model, Eur. J. Soil Sci., 58, 658-667, https://doi.org/10.1111/j.1365-2389.2006.00855.x, 2007. 